\title{
PHASE-TRANSFORMATION BEHAVIOR AND MICROMECHANICAL PROPERTIES OF A DUAL-PHASE STEEL AFTER CHEMICAL MODIFICATIONS
}

\author{
FAZNE SPREMEMBE IN MIKROMEHANSKE LASTNOSTI \\ DVOFAZNIH JEKEL PO KEMIJSKIH PRILAGODITVAH
}

\author{
Aijuan Zhao', Guoxin Zhao², Haijie Sun${ }^{1}$, Hairong Gao', Shaoqing Wang1, \\ Xiuli Chen ${ }^{1}$ \\ ${ }^{1}$ School of Chemistry and Chemical Engineering, Zhengzhou Normal University, Zhengzhou 450044, Henan, China \\ 2Institute of Chemical Industry and Food, Zhengzhou Institute of Technology, Zhengzhou 450044, Henan, China \\ mkyj2017@163.com \\ Prejem rokopisa - received: 2017-01-31; sprejem za objavo - accepted for publication: 2017-05-30
}

\begin{abstract}
In this work, the phase-transformation behavior and micromechanical properties of a dual-phase steel after chemical modifications were investigated theoretically and experimentally. In particular, the micromechanical behavior of the steel was modeled, based on the effects of the microstructure, phase fractions, local compositions of single phases and their area shapes. The developed model was used for predicting the damage behavior of a specimen. It was demonstrated that the tensile strength increased with the increasing temperature due to an increase in the amount of martensite in the steel, but the hardening behavior of this specimen was affected by the microstructure. Furthermore, the flow curves of the steel under different intercritical temperatures could be well predicted based on the real microstructures. The subsequent simulation results showed that while higher stress concentrated on the martensite, the shear-band appearance strongly depended on the microstructures of the phases. In addition, for the prediction of damage behaviors, the true stress/true strain curves of macroscale simulations showed good agreement with the experiments involving differently heat-treated steels.

Keywords: intercritical treatment, steel, micro model
\end{abstract}

$\mathrm{V}$ tem delu so teoretično in eksperimentalno preiskovali fazne spremembe in mikromehanske lastnosti dvofaznega jekla po kemijskih prilagoditvah. Se posebej je bilo modelirano mikromehansko obnašanje jekla glede na mikrostrukturo, deleže posameznih faz, lokalno sestavo posameznih faz in njihovo morfologijo. Razviti model je bil uporabljen za napoved poškodb vzorca. Dokazano je bilo, da se natezna trdnost povečuje $z$ naraščajočo temperaturo zaradi naraščanja vsebnosti martenzita $v$ jeklu, vendar je na kaljivost tega vzorca vplivala mikrostruktura. Nadalje je bilo ugotovljeno, da je možno krivulje tečenja jekla pri različnih interkritičnih temperaturah dobro napovedati na podlagi dejanskih mikrostruktur. Nadalje so rezultati simulacij pokazali, da so višje napetosti koncentrirane na martenzitu in istočasna prisotnost strižnih pasov, močno odvisne od mikrostruktur posameznih faz. Poleg tega je za napoved poškodb pomembno, da se prave krivulje napetost-deformacija, dobljene s pomočjo simulacij na makronivoju, dobro ujemajo z eksperimentalnimi, dobljenimi pri različno toplotno obdelanih jeklih.

Ključne besede: interkritična obdelava, jeklo, mikromodel

\section{INTRODUCTION}

In the past few decades, HSLA steels were widely used in the fields of pipelines, pressure vessels, heavy machinery, buildings, cars, bridges, offshore platforms and ships. ${ }^{1}$ However, with the development of the technology and deterioration of the environment, an even better performance of advanced steel was required, especially for the automotive industry. ${ }^{2}$ As a result, DP steels were developed. The matrix of DP steels consists of two different phases: ferrite and martensite; the former shows great plasticity and toughness, while the later shows high strength. Combining the two great performances, DP steels show great mechanical properties. ${ }^{3}$

The intercritical heat treatment, which involves holding in the two-phase $(\alpha+\gamma)$ region, followed by quick cooling, is frequently applied to obtain ferrite and martensite phases in a low-alloy steel. ${ }^{4-8}$ Previous investigations suggested that different chemical compositions, thermomechanical processing routes or heat treatments lead to different microstructural configurations, different phase-space distributions and other microstructure characteristics, affecting the deformation and failure behaviors of DP steels. ${ }^{9,10}$

Recently, researchers obtained the flow curves of the composite phases using micromechanical modelling based on the RVEs selected from a real microstructure. ${ }^{11-19}$ The flow behavior of a DP steel mainly depends on the properties of ferrite and martensite and the volume fractions of different phases. As steel has the same chemical composition, when modelling heat-treated steels, the model mainly focuses on the effects of strengthening methods and the grain size on the strength of different phases. With respect to material modeling, two equations, the Ashby-Orowan equation and 
A. J. ZHAO et al.: PHASE-TRANSFORMATION BEHAVIOR AND MICROMECHANICAL PROPERTIES ...

Table 1: Chemical composition of Gr.65 steel

\begin{tabular}{|c|c|c|c|c|c|c|c|c|c|c|c|}
\hline Elements & $\mathrm{C}$ & $\mathrm{Si}$ & $\mathrm{Mn}$ & $\mathrm{P}$ & $\mathrm{S}$ & $\mathrm{Al}$ & $\mathrm{V}$ & $\mathrm{Ti}$ & $\mathrm{Cr}$ & $\mathrm{Nb}$ & $\mathrm{Fe}$ \\
\hline$w / \%$ & 0.13 & 0.3 & 1.4 & 0.014 & 0.002 & 0.03 & 0.043 & 0.014 & 0.06 & 0.031 & Balance \\
\hline
\end{tabular}

Hall-Petch equation, were taken into account when describing the flow-stress behavior of steel. ${ }^{12}$

Moreover, in actual engineering, the predictions of deformation and failure behaviors of DP steels are the final purpose. Some of the available damage models such as the ones of the aforementioned failure mechanisms, the Gurson-Tvergaard-Needleman (GTN) damage model, the extended finite-element model (XFEM), the cohesive-zone model and so on, were closely estimated for the experiments. ${ }^{20-23}$

A. Ramazani et al. investigated the effect of an inhomogeneous morphology on the mechanical properties of a welded joint. ${ }^{15}$ 2D RVEs simulated flow curves were corrected to $3 \mathrm{D}$ ones, taking into account the effects of the microstructure, the chemical composition and the area fraction on the macroscopic mechanical properties of the welded joint. Finally, the tensile test of the welded material with the inhomogeneous morphology was simulated and good agreement between the experimental and predicted flow curves was achieved.

The aim of this work was to predict the damage behavior of an HSLA steel under different intercriticaltemperature conditions and to establish a relational model presenting the connection between the microstructure and macromechanics of materials to provide guidance for material design based on the microstructure.

\section{EXPERIMENTAL PART}

The as-received material was the Gr.65 steel, a highstrength low-alloy structural steel (with a yield strength of 460MPa), supplied as a hot-roll plate. Table 1 gives the chemical composition of the steel. The initial microstructure mainly consisted of ferrite with a small amount of pearlite, shown in Figure 1.

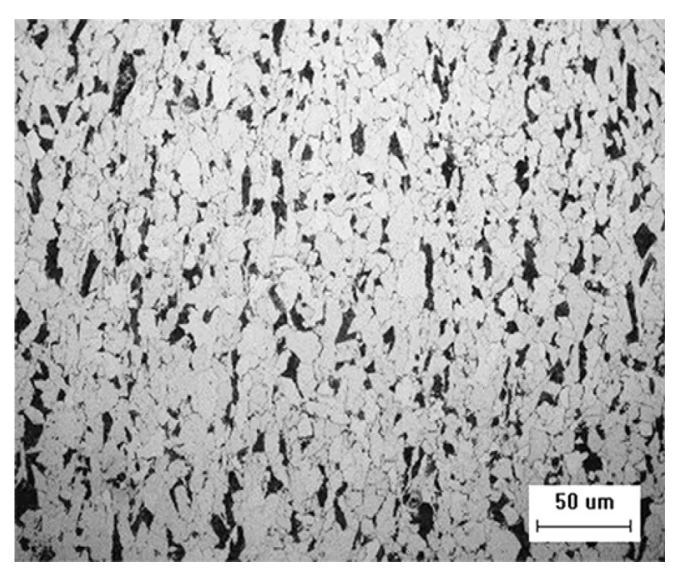

Figure 1: Original microstructure of Gr. 65 steel in OM

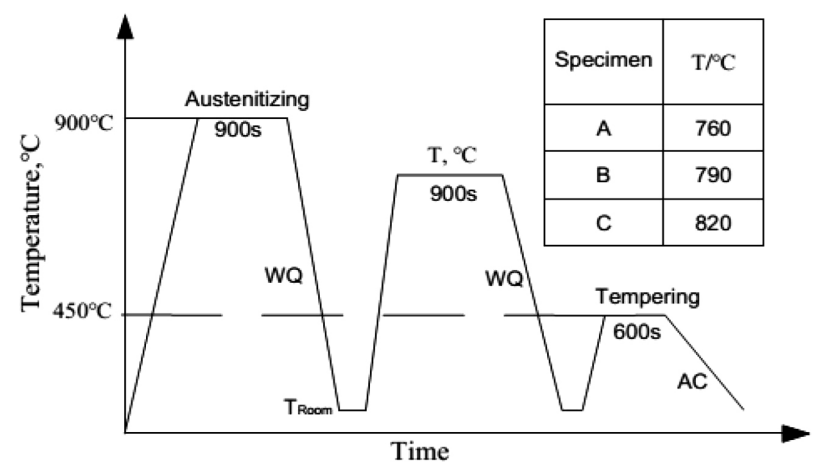

Figure 2: Heat-treatment regime for the samples

All of the specimens cut along the rolling direction of the plate, with dimensions of $70 \mathrm{~mm} \times 40 \mathrm{~mm} \times 4 \mathrm{~mm}$ (length, width and thickness) underwent heat treatment in a resistance furnace, and the heat-treatment regime is illustrated on Figure 2. The specimens were first austenitized at $900{ }^{\circ} \mathrm{C}$ for $15 \mathrm{~min}$, followed by water cooling to get the martensite phase, then reheated to different intercritical temperatures $(760,790$ and 820$){ }^{\circ} \mathrm{C}$ for 15 min and water cooled again to get a ferrite-martensite microstructure. Then, all the specimens were tempered at $450{ }^{\circ} \mathrm{C}$ for a holding time of $10 \mathrm{~min}$ and air cooled to room temperature. After the heat treatments, the specimens were ground, polished and etched for metallographic analyses.

Figure 3 shows the geometry of the specimens for tensile testing. The tensile specimens were tested at a strain rate of $0.00033 \mathrm{~s}^{-1}$. The force and displacement curves were recorded by means of a load cell and extensometer (in this study, the length of the extensometer was $12.5 \mathrm{~mm}$ ) during the tests. Later, the stress/strain curves of the steels were calculated at room temperature.

\section{NUMERICAL APPROACH}

\subsection{Micromechanical modeling}

Recently, the model based on the Ashby-Orowan equation and Hall-Petch equation was usually used to

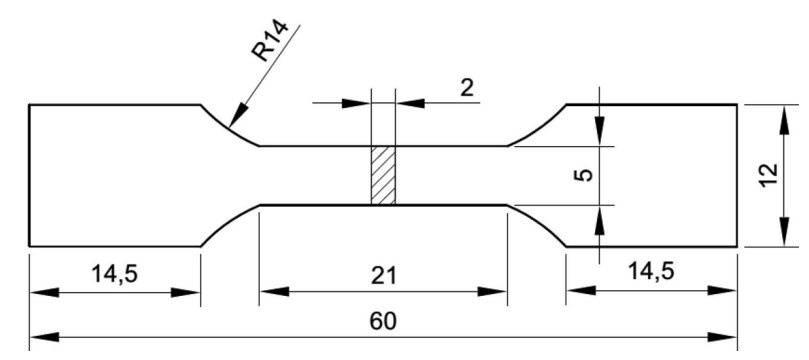

Figure 3: Geometry of a specimen for tensile testing 
predict the flow-stress behavior of each phase in the steel. ${ }^{1-15,18}$ The former equation represents the material strengthening due to the carbon content and other alloying elements' carbide precipitation, while the latter is based on the dislocation theory determining the effects of the grain size. ${ }^{12}$ The approach can be expressed as Equation (1):

$$
\sigma=\sigma_{0}+\Delta \sigma_{\mathrm{s}}+\alpha M \mu \sqrt{b} \sqrt{\frac{1-\exp (-M k \varepsilon)}{k L}}
$$

where $\sigma$ is the flow stress and $\varepsilon$ is the true strain. The first term $\sigma_{0}$ takes care of the Peierls stress and the effects of the elements in a solid solution (Equation (2)). The second term is the solid-solution strengthening due to the carbon content (Equations (3) and (4)). $\alpha$ is the material constant, $M$ is the Taylor factor, $\mu$ is the shear modulus, $b$ is the Burgers vector, $k$ is the recovery rate and $L$ describes the dislocation mean free path.

$\sigma_{0}($ in $\mathrm{MPa})=77+750(\% \mathrm{P})+60(\% \mathrm{Si})+80(\% \mathrm{Cu})+$

$+45(\% \mathrm{Ni})+60(\% \mathrm{Cr})+80(\% \mathrm{Mn})+11(\% \mathrm{Mo})$

From the literature, the values for parameters $\alpha, M, \mu$, and $b$ were $0.33,3,80000 \mathrm{MPa}$, and $2.5 \cdot 10^{-10} \mathrm{~m}$. For ferrite, the $k$ value used is $10^{-5} / d_{\alpha}$, where $d_{\alpha}$ is the ferrite gain size. For martensite, two constants, 41 and 0.038 , were used to define $k$ and $L .^{11,13,15,18}$

The second term is the solid-solution strengthening due to the carbon and nitrogen contents. For ferrite, it is:

$$
\Delta \sigma_{\mathrm{s}}=5000\left(\% \mathrm{C}_{\mathrm{ss}}^{\mathrm{f}}+\% \mathrm{~N}_{\mathrm{ss}}^{\mathrm{f}}\right)
$$

while for martensite, it is

$$
\Delta \sigma_{\mathrm{s}}=3605\left(\% \mathrm{C}_{\mathrm{ss}}^{\mathrm{m}}+\% \mathrm{~N}_{\mathrm{ss}}^{\mathrm{m}}\right)-161
$$

where $\mathrm{C}_{\mathrm{ss}}^{\mathrm{f}}$ and $\% \mathrm{~N}_{\mathrm{ss}}^{\mathrm{f}}$ denote the carbon and nitrogen contents in the solid solution $(w / \%)$ in ferrite, $\mathrm{C}_{\mathrm{ss}}^{\mathrm{m}}$ and $\% \mathrm{~N}_{\mathrm{ss}}^{\mathrm{m}}$ are the carbon and nitrogen contents in the solid solution in martensite, respectively. The values of the carbon and nitrogen contents were computed with software JMatPro.

\subsection{Macromechanical modeling}

2D RVE was generated based on real micrographs and can involve all the microstructural features in the calculations. However, a specimen deforms three-dimensionally during the uniaxial tensile test and 2D-modeling approaches are not able to predict the flow curve of a material precisely. Therefore, in order to study the effects of microstructural features on the mechanical properties of a heat-treated steel, the predicted flow curves of $2 \mathrm{D}$ modeling should be correlated to the 3Ds by introducing a correlation factor. A. Ramazani et al. ${ }^{11}$ introduced a function as $\sigma_{3 \mathrm{D} /} \sigma_{2 \mathrm{D}}$ to describe the correlation between the 2D and 3D flow-curve modelling of DP steels. The function mainly considered the effect of the martensite volume fraction and the equivalent plastic strains under the 2D FE simulation and provided some influence exponentials, as shown in Equation (5). Therefore, the developed flow curves from 2D RVE calcula- tions were corrected to 3D curves using Equation (5). These corrected flow curves are used as input data for macromechanical modeling.

$$
\begin{aligned}
& \sigma_{3 \mathrm{D}} / \sigma_{2 \mathrm{D}}=2 \times 10^{-4} \times\left(\varepsilon_{\mathrm{eq}}^{\mathrm{p}}\right)^{2} \times V_{\mathrm{m}}^{3}+1 \times 10^{-7} V_{\mathrm{m}}^{3}+ \\
& +0.0218 \times\left(\varepsilon_{\mathrm{eq}}^{\mathrm{p}}\right)^{2} \times V_{\mathrm{m}}^{2}+7 \times 10^{-5} \times V_{\mathrm{m}}^{2}+0.18 \times\left(\varepsilon_{\mathrm{eq}}^{\mathrm{p}}\right)^{2} \times \\
& \times V_{\mathrm{m}}+0.007 \times\left(\varepsilon_{\mathrm{eq}}^{\mathrm{p}}\right)^{2} \times V_{\mathrm{m}}+0.0036 \times\left(\varepsilon_{\mathrm{eq}}^{\mathrm{p}}\right)^{2} \times V_{\mathrm{m}}+1
\end{aligned}
$$

where $\sigma_{3 \mathrm{D}}$ and $\sigma_{2 \mathrm{D}}$ are the $3 \mathrm{D}$ and $2 \mathrm{D}$ flow stresses, $V_{\mathrm{m}}$ and $\varepsilon_{\mathrm{eq}}^{\mathrm{p}}$ are the martensite volume fraction and equivalent plastic strains under the $2 \mathrm{D}$ FE simulation.

In order to study the microstructure-based failure of the intercritically heat-treated HSLA steel, a GTN model was applied to investigate the damage behavior of the material at the macroscale. The GTN model is formulated as Equation (6):

$\Phi_{\mathrm{GTN}}=\left(\frac{\sigma_{\mathrm{v}}}{\sigma_{y}}\right)^{2}+2 q_{1} \cdot f^{*} \cosh \left(\frac{3}{2} q_{2} \frac{\sigma_{\mathrm{H}}}{\sigma_{y}}\right)-\left(1+q_{3} f^{* 2}\right)=0$

where $\sigma_{\mathrm{v}}, \sigma_{\mathrm{y}}$ and $\sigma_{\mathrm{H}}$ are the von Mises equivalent stress, the matrix-material yield stress and the hydrostatic stress; $q_{1}, q_{2}$ and $q_{3}$ are the model parameters, in practice, $q_{1}=1.5, q_{2}=1$ and $q_{3}=\left(q_{1}\right)^{2}=2.25 .{ }^{24}$ Function $f^{*}$ was introduced by V. Tvergaard and A. Needleman ${ }^{25}$ to describe the effect of a void interaction starting during the failure process (Equation (7)):

$$
f^{*}=\left\{\begin{array}{l}
f ; f \leq f_{\mathrm{c}} \\
f_{\mathrm{c}}+\frac{1 / q_{1}-f_{\mathrm{c}}}{f_{\mathrm{F}}-f_{\mathrm{c}}}\left(f-f_{\mathrm{c}}\right) ; f>f_{\mathrm{c}}
\end{array}\right.
$$

were $f, f_{\mathrm{c}}$ and $f_{\mathrm{F}}$ are the void volume fraction, the critical void volume fraction at the onset of void coalescence, and the void volume fraction at failure, respectively. The whole void-volume-fraction development is defined as the sum of the growth of the existing voids: $\dot{f}_{\text {growth }}$ and the nucleation of new voids $\dot{f}_{\text {nucleation }}$.

As the matrix material is considered to be incompressible, $\dot{f}_{\text {growth }}$ is defined by the volumetric part of the plastic-strain rate $\dot{\varepsilon}_{\mathrm{kk}}$ :

$$
\dot{f}_{\text {growth }}=(1-f) \cdot \dot{\varepsilon}_{\mathrm{kk}}
$$

C. C. Chu and A. Needleman ${ }^{26}$ assumed that the strain controlled the void-nucleation mechanism, following a normal distribution. $\dot{f}_{\text {nucleation }}$ is defined by the rate of the equivalent plastic strain $\dot{\bar{\varepsilon}}$ in Equation (9):

$$
\dot{f}_{\text {nucleation }}=A \cdot \dot{\bar{\varepsilon}}
$$

where

$A=\frac{f_{\mathrm{N}}}{s_{\mathrm{N}} \sqrt{2 \pi}} \exp \left[-\frac{1}{2}\left(\frac{\bar{\varepsilon}-\varepsilon_{\mathrm{N}}}{S_{\mathrm{N}}}\right)^{2}\right] \cdot \bar{\varepsilon}$,

$f_{\mathrm{n}}$ is the volume fraction of the secondary voids, $\varepsilon_{\mathrm{N}}$ and $S_{\mathrm{N}}$ are the mean value and the standard deviation of the 


\section{A. J. ZHAO et al.: PHASE-TRANSFORMATION BEHAVIOR AND MICROMECHANICAL PROPERTIES ...}

characteristic plastic-strain distribution, $\bar{\varepsilon}$ and $\dot{\bar{\varepsilon}}$ are the equivalent plastic strain and the rate of the equivalent plastic strain, respectively.

Finally, the damage-evolution law is given as:

$f=\dot{f}_{\text {growth }}+\dot{f}_{\text {nucleation }}=(1-f) \cdot \dot{\varepsilon}_{\mathrm{kk}}+$

$+\frac{f_{\mathrm{N}}}{s_{\mathrm{N}} \sqrt{2 \pi}} \exp \left[-\frac{1}{2}\left(\frac{\bar{\varepsilon}-\varepsilon_{\mathrm{N}}}{S_{\mathrm{N}}}\right)^{2}\right] \cdot \bar{\varepsilon}$

In this damage model, $\varepsilon_{\mathrm{N}}$ and $S_{\mathrm{N}}$ were assumed to be 0.3 and 0.1 , while the other parameters were determined with a calibration of the numerical results using experimental data. ${ }^{24}$

\subsection{Macro/microscopic finite-element model and boun- dary conditions}

All the associated numerical models were performed with the finite-element software ABAQUS. Figure 4a shows the macroscopic finite-element model for a tensile-test specimen, and the specimen was modeled with solid, reduced-integration element C3D8R. The boundary condition and the load plan, according to which the upper part of the specimen was stretched and the bottom was fixed was consistent with the real condition.

In the case of the macroscopic finite-element simulations, all the specimens were generally considered as continuous and homogeneous. On the microscale, each constituent character of the microstructure of a steel specimen needed to be incorporated. RVE was applied to take into account the influences of different deformation behaviors of each phase on the resulting mechanical properties. The 2D RVE models were generated from real microstructures modeled with plane strain element CPE4R in ABAQUS. The selection requirement is that the volume percent of martensite is the same with the real microstructure in $2 \mathrm{D}$ RVE. The boundary condition

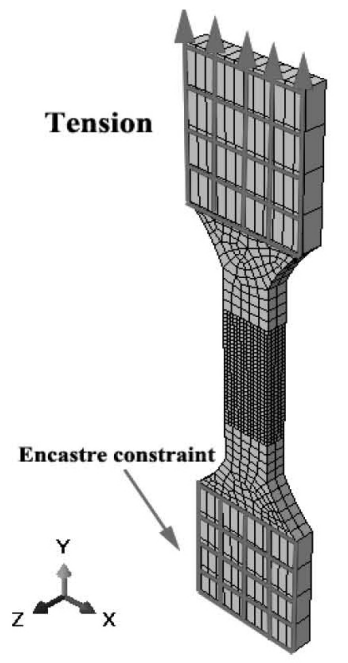

(a)

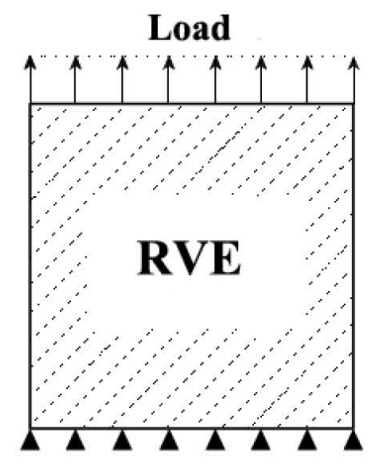

(b)
Figure 4: a) Macrostructural finite-element mode, b) microstructural finite-element model and load plan are shown in Figure $4 \mathbf{b}$; the bottom of 2D RVE is fixed and the top of it is pulled.

\section{RESULTS AND DISCUSSION \\ 4.1 Microscale simulation results}

Intercritical temperature $T$, ferrite grain size $d_{\alpha}$, martensite fraction $V_{\mathrm{m}}$, along with the carbon content in ferrite $\mathrm{C}_{\mathrm{ss}}^{\mathrm{f}}$ and in martensite $\mathrm{C}_{\mathrm{ss}}^{\mathrm{m}}$ are listed in Table 2. After calculating the nitrogen content, we found that the effect of the nitrogen content on the solid-solution strengthening was extremely minimal, so we ignored the nitrogen contents in ferrite and martensite. In general, the parameter has a monotonous trend with an increase in the temperature $\left(760{ }^{\circ} \mathrm{C}\right.$ to $\left.820{ }^{\circ} \mathrm{C}\right)$, except for the ferrite grain.

Table 2: Model parameters for the flow-curve prediction for individual phases

\begin{tabular}{|c|c|c|c|c|c|}
\hline Specimen & $T\left({ }^{\circ} \mathrm{C}\right)$ & $d_{\alpha}(\mathrm{m})$ & $V_{\mathrm{m}}(\%)$ & $\mathrm{C}_{\mathrm{ss}}^{\mathrm{f}}(\%)$ & $\mathrm{C}_{\mathrm{ss}}^{\mathrm{m}}(\%)$ \\
\hline $\mathrm{A}$ & 760 & 5.28 & $48 \%$ & 0.00688 & 0.33 \\
\hline $\mathrm{B}$ & 790 & 2.31 & $57 \%$ & 0.0059 & 0.21 \\
\hline $\mathrm{C}$ & 820 & 4.17 & $69 \%$ & 0.00455 & 0.13 \\
\hline
\end{tabular}

Figure 5 exhibits the stress/strain curve for micromechanical modelling. It can be seen that ferrite shows a ductile hardening behavior, whereas martensite is more brittle and also shows a higher strength. In this study, the grain size and the carbon content played important roles in the computed yield curves for ferrite and materials. From Table 2 and Figure 5, the solute carbon content limits the yield strength of martensite, while the ultimate stress of ferrite is dependent on the grain size.

The microstructure in $\mathrm{OM}$ and the selections of $2 \mathrm{D}$ RVEs from the real microstructures at different intercritical temperatures are displayed in Figure 6. The phases of all the specimens were ferrite and martensite, and after different intercritical temperatures, the phases

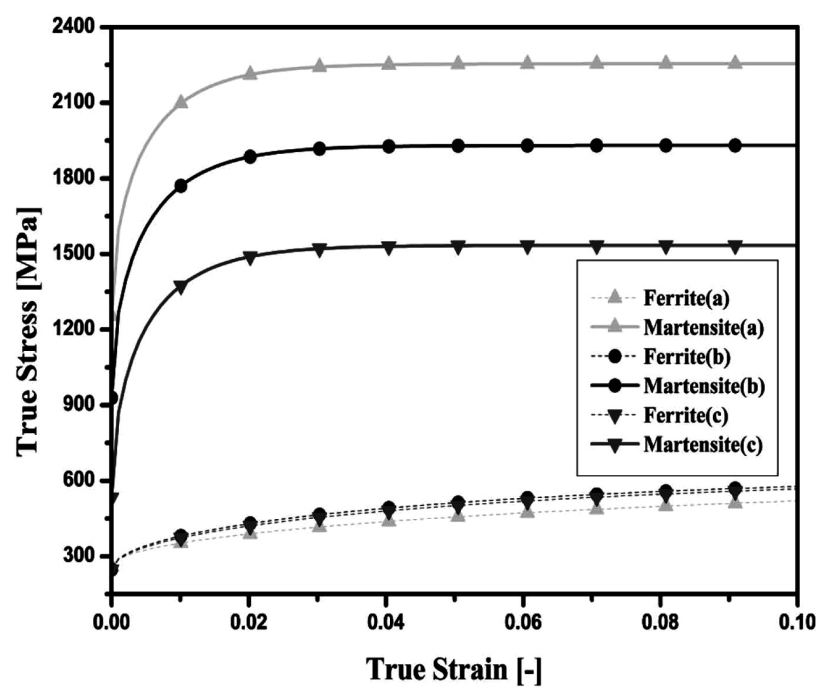

Figure 5: Flow curves for ferrite and martensite phases in a specimen 
A. J. ZHAO et al.: PHASE-TRANSFORMATION BEHAVIOR AND MICROMECHANICAL PROPERTIES ...
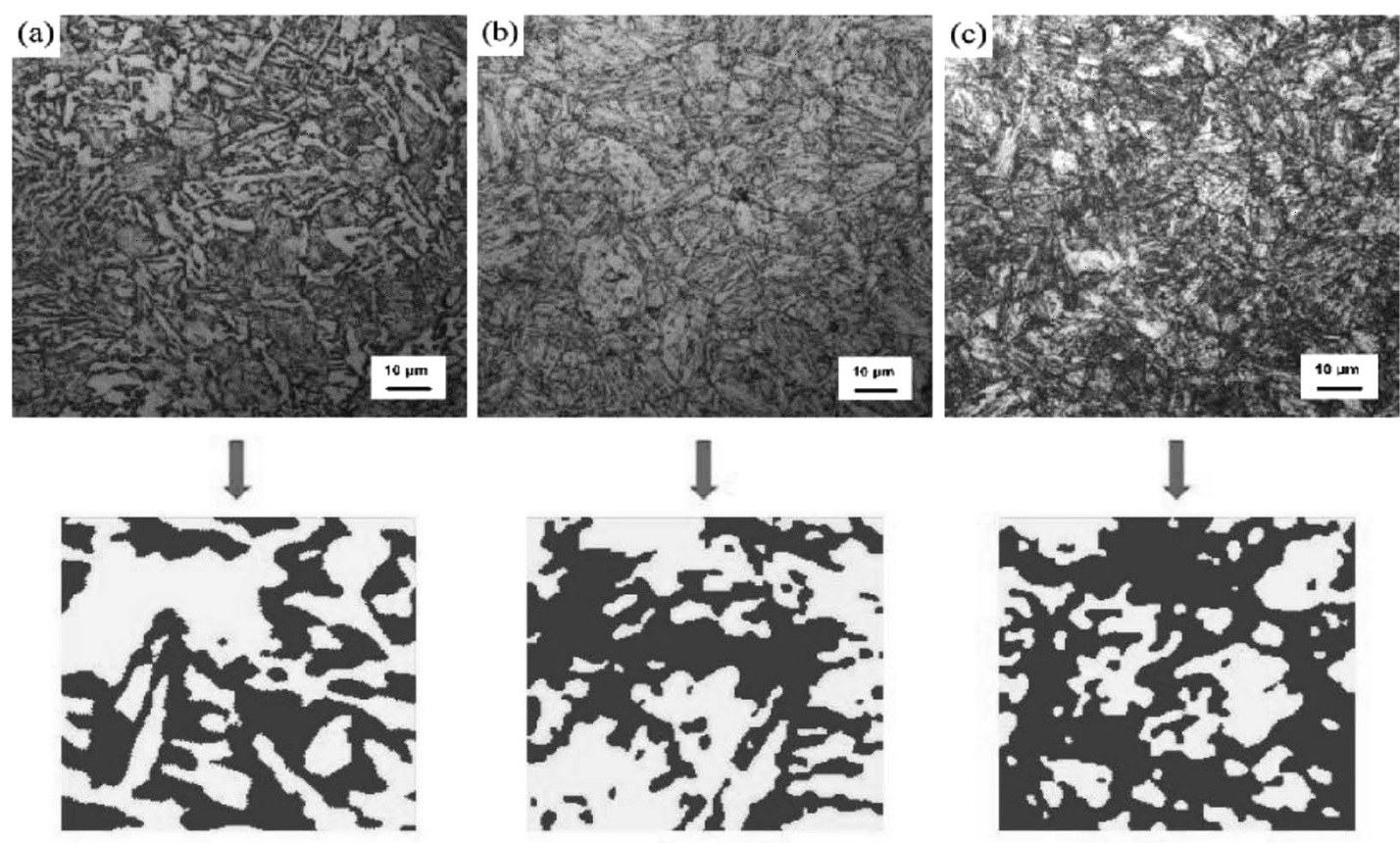

Ferrite

\section{Martensite}

Figure 6: Microstructure in $\mathrm{OM}$ and selections of $2 \mathrm{D}$ RVEs from real microstructures at different intercritical temperatures: a) $760{ }^{\circ} \mathrm{C}$, b) $790{ }^{\circ} \mathrm{C}$ and c) $820^{\circ} \mathrm{C}$

presented different microstructures. After the heat treatment (at $760{ }^{\circ} \mathrm{C}$ ), lath martensite and banded ferrite coexisted in steel, as shown in Figure 6a. When the second quenching temperature was $790{ }^{\circ} \mathrm{C}$, the grain boundaries were clear and the parallel lath martensite was distributed in the grains (Figure 6b). The amount of
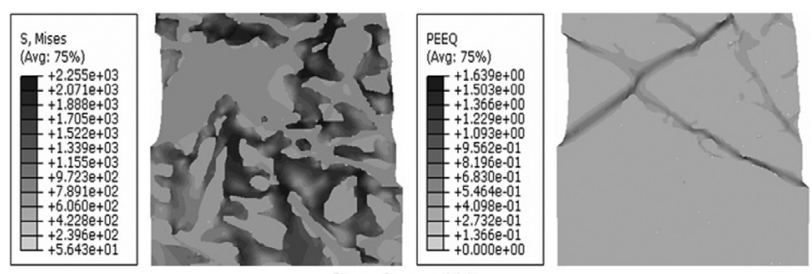

Specimen(A)
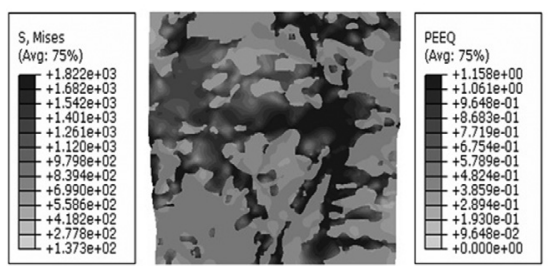

Specimen(B)
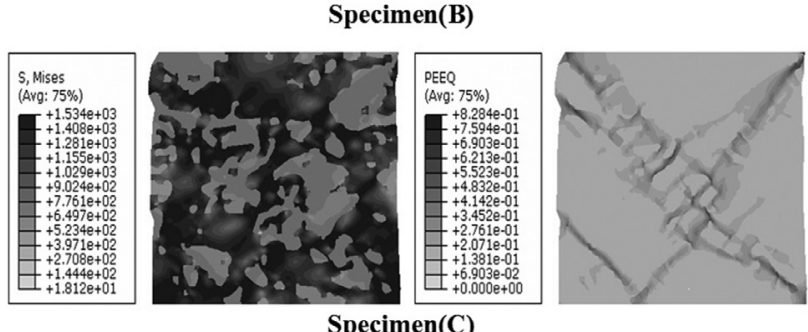

Specimen(C)

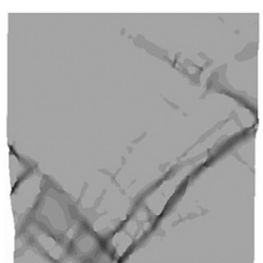

Figure 7: Von Mises stress distributions (left) and equivalent plasticstrain distributions (right) on 2D RVEs lath martensite increased and the grain boundaries disappeared at $820{ }^{\circ} \mathrm{C}$ (Figure 6c).

After a $5 \%$ deformation, the von Mises stress and equivalent plastic-strain distributions for the specimens were simulated; the results are shown in Figure 7. It can be clearly concluded that the stress is mainly carried by martensite, and a higher stress difference exists between the ferrite and martensite phases due to the von Mises stress distributions. For the first specimen, the maximum stress mainly focuses on the small connecting belt among the martensite grains (Figure 7a). Regarding the second specimen, the maximum stress is mainly distributed along the lath martensite (Figure 7b). The last specimen's maximum stress is distributed uniformly in martensite (Figure 7c). Furthermore, the equivalent plastic-strain distributions show shear bands in the ferrite areas; it is easily seen that the amount of shear bands of specimen (A) is low, while more shear bands consist in specimen (C).

Because of different microstructures, there are some differences in the shape of fracture surfaces. On the first specimen, there are more shear-fracture dimples on the fracture face and a tearing dimple is shown (Figure 8a). For the second specimen, tear dimples are obviously seen from the fracture morphology; its fracture tearing edge is higher and the tearing dimple is deeper (Figure 8b). For the third specimen, the micro-fracture morphology shows some large equiaxed dimples (Figure 8c).

Therefore, the effective stress/strain and workhardening-rate/true-strain curves from the 2D RVE calculations were corrected to 3D curves using Equation 
A. J. ZHAO et al.: PHASE-TRANSFORMATION BEHAVIOR AND MICROMECHANICAL PROPERTIES ...
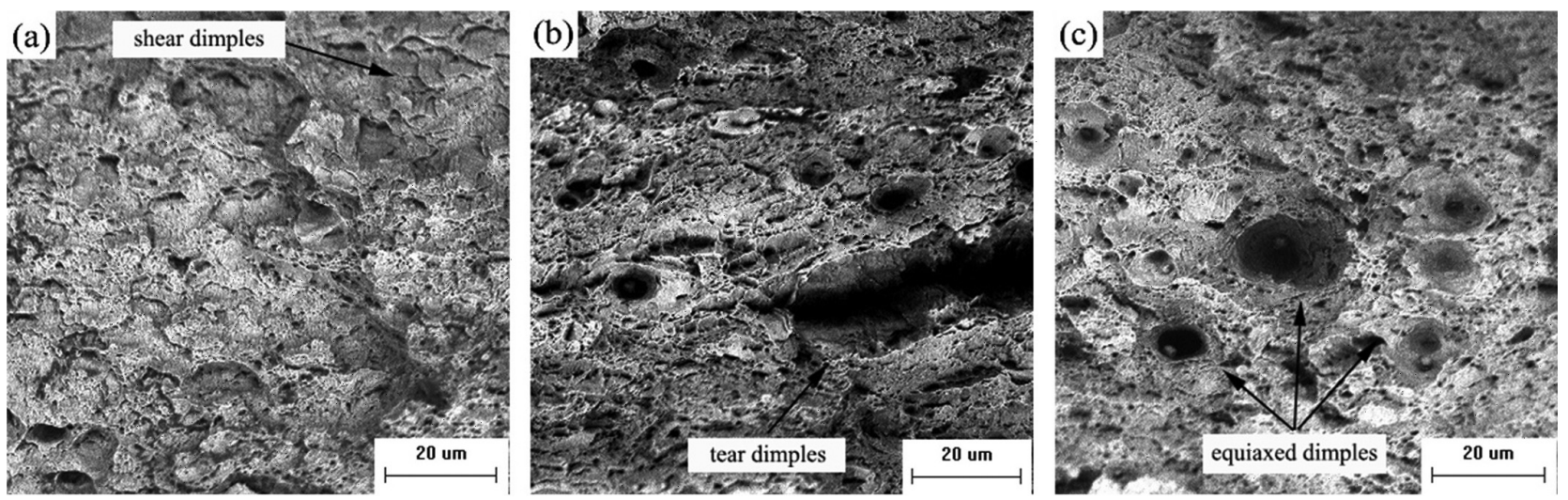

Figure 8: Fracture surfaces of the heat-treated specimens at different intercritical temperatures: a) $760{ }^{\circ} \mathrm{C}$, b) $790{ }^{\circ} \mathrm{C}$ and c) $820{ }^{\circ} \mathrm{C}$

(5). These corrected curves are shown in Figure 9; specimen (B) shows the highest work hardening behaviors, higher stress level and yield stress.

\subsection{Macroscale simulation results}

The flow curves were obtained through micromechanical modeling and inputted into the macromechanical

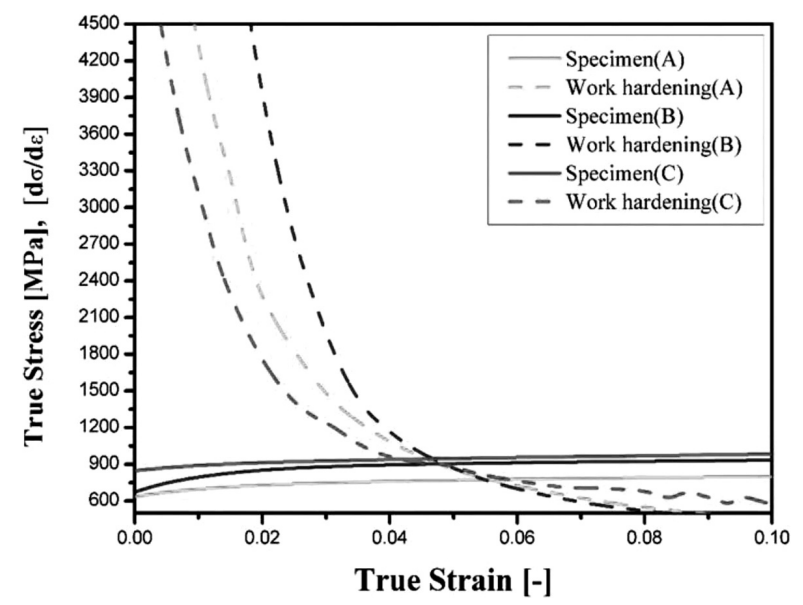

Figure 9: True stress/strain and work-hardening curves obtained through micromechanical modeling

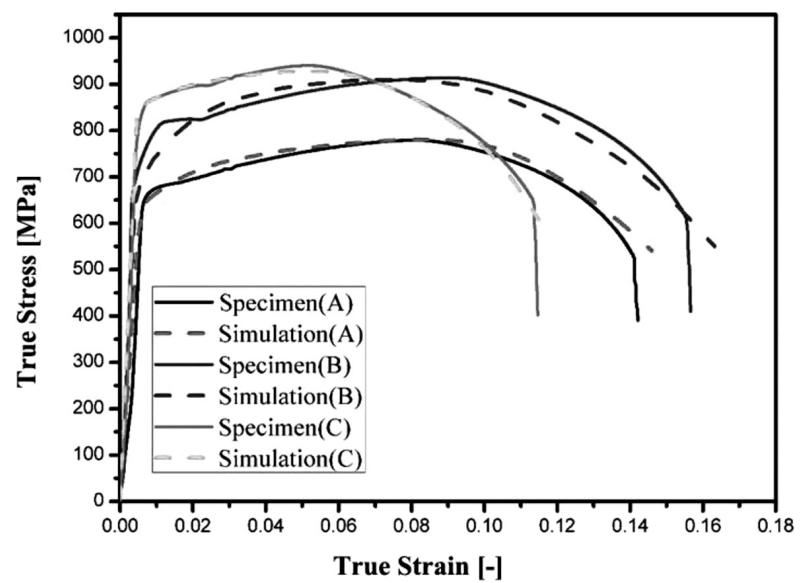

Figure 10: Experimental and simulated stress/strain curves of intercritically heat-treated steels model. Subsequently, the GTN damage model was applied to investigate the failure behavior of the material. After macromechanical modeling, the stress/strain curves of the simulation were compared with the experimental curves, as shown in Figure 10. It can be observed that the macromechanical model based on the flow curves of micromechanical modeling provides very good estimates for the experimental results.

The equivalent plastic-strain distribution and voidvolume-fraction distribution in tensile samples $(1 / 2$ part of the extensometer measurement) at a $6 \%$ deformation are shown in Figure 11. After the deformation due to the engineering strain of $6 \%$, the plastic strain and void

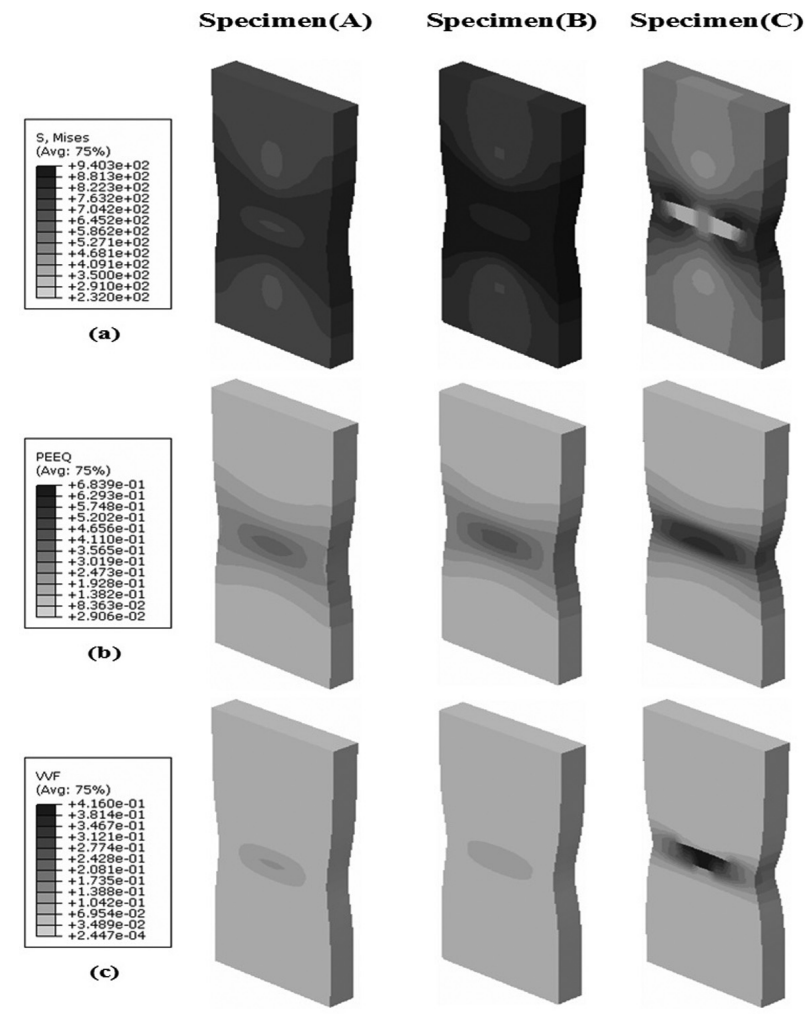

Figure 11: a) Equivalent plastic-strain distribution, b) void-volumefraction distribution in $1 / 2$ part of the extensometer measurement, at a deformation of $6 \%$ 


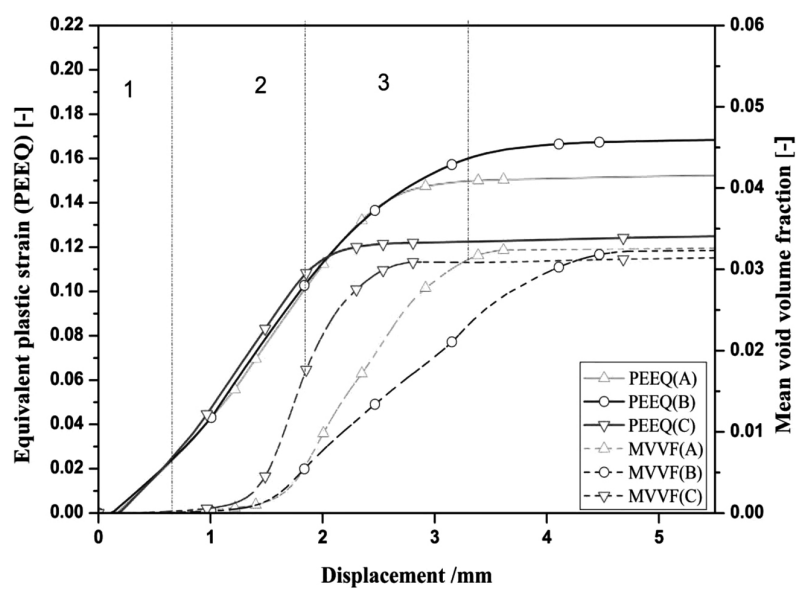

Figure 12: Comparison between the equivalent plastic strain and mean void volume fraction during loading

volume fraction mainly focus on the core of a specimen. For specimen (A), the equivalent plastic strain is the smallest, but the void volume fraction is the largest for specimen $(\mathrm{C})$.

In addition, development curves of the equivalent plastic strain and the mean void volume fraction were calculated during the simulation process. With an increase in the displacement, the development trends of the equivalent plastic strain and the mean void volume fraction for different specimens were similar, as shown in Figure 12. It can be seen that there are three processes (we took the third specimen as an example).

During the first stage, the growth rate of the equivalent plastic strain is almost constant and the mean void volume fraction initially remained unchanged, followed by a slow increase, which shows that the specimen is in the state of uniform deformation. After the first stage, the equivalent plastic strain increases rapidly and the volume fraction of voids increases greatly, which means the specimen goes into the inhomogeneous deformation stage and a lot of voids begin to form and grow up. During the last stage, the mean volume fraction of voids and the equivalent plastic strain continue to increase, followed by a slow increase, and come to be maximum in the end. This illustrates that the coalescence of voids plays an import part in the third stage. For the specimen, large cracks are formed and the sample finally breaks. After the comparison between the equivalent plastic strain and the mean void volume fraction, we can see that specimen (B) shows a great elongation performance because of the lowest void-volume-fraction growth rate (Figure 12).

\section{CONCLUSIONS}

The Gr.65 steel underwent an intercritical heat-treatment process. The micromechanical properties of the heat-treated steel were predicted, taking into account the effects of the microstructure, phase fractions, local compositions of single phases and their area shapes. The
GTN model was used for predicting the damage behavior of the specimens for the macromechanical model. The following points could be drawn:

1) The tensile strength increased with the increasing temperature due to an increase in the amount of martensite in the steel, but the hardening behavior of this specimen was affected by the microstructure.

2) The flow curves of the Gr.65 steel at different interitical temperatures could be well predicted using the 2D FE simulation based on real microstructures. Simulation results showed that higher stress concentrated on the martensite; at the same time, the shear-band appearance strongly depended on the microstructures of the phases.

3) For the prediction of damage behaviors, the true stress/true strain curves of macroscale simulations showed good agreement with the experiments involving differently heat-treated steels.

\section{REFERENCES}

${ }^{1}$ H. J. Jun, J. S. Kang, D. H. Seo, F. K. Kim, Effects of deformation and boron on microstructure and continuous cooling transformation in low carbon HSLA steels, Materials Science and Engineering A, 422 (2006) 1, 157-162, doi:10.1016/j.msea.2005.05.008

${ }^{2}$ S. Oliver, T. B. Jones, G. Fourlaris, Dual phase versus TRIP strip steels: comparison of dynamic properties for automotive crash performance, Materials Science and Technology, 23 (2007) 4, 423-431, doi:10.1179/174328407X168937

${ }^{3}$ Y. I. Son, Y. K. Lee, K. T. Park, Ultrafine grained ferrite-martensite dual phase steels fabricated via equal channel angular pressing: microstructure and tensile properties, Acta Materialia, 53 (2005) 11, 3125-3134, doi:10.1016/j.actamat.2005.02.015

${ }^{4}$ L. Shi, Z. Yan, Y. Liu, D. G. Li, Improved toughness and ductility in ferrite/acicular ferrite dual-phase steel through intercritical heat treatment, Materials Science and Engineering A, 590 (2005), 7-15, doi:10.1016/j.msea.2005.10.006

${ }^{5}$ J. Kang, C. Wang, G. D. Wang, Microstructural characteristics and impact fracture behavior of a high-strength low-alloy steel treated by intercritical heat treatment, Materials Science and Engineering A, 553 (2012), 96-104, doi:10.1016/j.msea.2012.05.098

${ }^{6}$ Z. J. Xie, S. F. Yuan, W. H. Zhou, G. D. Wang, Stabilization of retained austenite by the two-step intercritical heat treatment and its effect on the toughness of a low alloyed steel, Materials \& Design, 59 (2014), 193-198, doi:10.1016/j.matdes.2014.02.035

${ }^{7}$ M. A. Maleque, Y. M. Poon, H. H. Masjuki, The effect of intercritical heat treatment on the mechanical properties of AISI 3115 steel, Journal of Materials Processing Technology, 153 (2004), 482-487, doi:10.1016/j.jmatprotec.2004.04.391

${ }^{8}$ W. H. Zhou, X. L. Wang, P. K. C. Venkatsurya, R. F. Shi, Structure-mechanical property relationship in a high strength low carbon alloy steel processed by two-step intercritical annealing and intercritical tempering, Materials Science and Engineering A, 607 (2014), 569-577, doi:10.1016/j.msea.2014.03.107

${ }^{9}$ M. Azuma, S. Goutianos, N. Hansen, D. F. White, Effect of hardness of martensite and ferrite on void formation in dual phase steel, Materials Science and Technology, 28 (2012) 9, 1092-1100, doi:10.1179/1743284712Y.0000000006

${ }^{10}$ B. C. Hwang, T. Y. Cao, S. Y. Shin, F. H. Kim, Effects of ferrite grain size and martensite volume fraction on dynamic deformation behaviour of $0.15 \mathrm{C}-2.0 \mathrm{Mn}-0.2 \mathrm{Si}$ dual phase steels, Materials Science and Technology, 21 (2005) 8, 967-975, doi:10.1179/ 174328405 X47609 


\section{MATERIALI IN TEHNOLOGIJE/MATERIALS AND TECHNOLOGY (1967-2017) - 50 LET/50 YEARS}

\section{A. J. ZHAO et al.: PHASE-TRANSFORMATION BEHAVIOR AND MICROMECHANICAL PROPERTIES ...}

${ }^{11}$ A. Ramazani, K. Mukherjee, H. Quade, D. H. Gray, Correlation between $2 \mathrm{D}$ and $3 \mathrm{D}$ flow curve modelling of DP steels using a microstructure-based RVE approach, Materials Science and Engineering A, 560 (2013), doi:10.1016/j.msea.2012.09.046

${ }^{12} \mathrm{P}$. Phetlam, V. Uthaisangsuk, Microstructure based flow stress modeling for quenched and tempered low alloy steel, Materials \& Design, 82 (2015), 189-199, doi:10.1016/j.matdes.2015.05.068

${ }^{13}$ A. Ramazani, K. Mukherjee, U. Prahl, Modelling the effect of microstructural banding on the flow curve behaviour of dual-phase (DP) steels, Computational Materials Science, 52 (2012) 1, 46-54, doi:10.1016/j.commatsci.2011.05.041

${ }^{14}$ M. R. Ayatollahi, A. C. Darabi, H. R. Chamani, 3D Micromechanical Modeling of Failure and Damage Evolution in Dual Phase Steel Based on a Real 2D Microstructure, Acta Mechanica Solida Sinica, 29 (2016) 1, 95-110, doi:10.1016/S0894-9166(16)60009-5

${ }^{15}$ A. Ramazani, K. Mukherjee, A. Abdurakhmanov, Micro-macrocharacterisation and modelling of mechanical properties of gas metal arc welded (GMAW) DP600 steel, Materials Science and Engineering A, 589 (2014), 1-14, doi:10.1016/j.msea.2013.09.056

${ }^{16}$ S. M. K. Hosseini, A. Zarei-Hanzaki, M. J. Y. Panah, A. G. Amire, ANN model for prediction of the effects of composition and process parameters on tensile strength and percent elongation of $\mathrm{Si}-\mathrm{Mn}$ TRIP steels, Materials Science and Engineering A, 374 (2004) 1, 122-128, doi:10.1016/j.msea.2004.01.007

${ }^{17}$ M. I. Latypov, S. Shin, B. C. De Cooman, Micromechanical finite element analysis of strain partitioning in multiphase medium manganese TWIP+ TRIP steel, Acta Materialia, 108 (2016), 219-228, doi:10.1016/j.actamat.2016.02.001

${ }^{18}$ A. Ramazani, M. Abbasi, U. Prahl, Failure analysis of DP600 steel during the cross-die test, Computational Materials Science, 64 (2012), 101-105, doi:10.1016/j.commatsci.2012.01.031
${ }^{19}$ B. Berisha, C. Raemy, C. Becker, Multiscale modeling of failure initiation in a ferritic-pearlitic steel, Acta Materialia, 100 (2015), 191-201, doi:10.1016/j.actamat.2015.08.035

${ }^{20}$ A. L. Gurson, Continuum theory of ductile rupture by void nucleation and growth: Part I - Yield criteria and flow rules for porous ductile media, Journal of Engineering Materials and Technology, 99 (1977) 1, 2-15, doi:10.1115/1.3443401

${ }^{21}$ V. Tvergaard, A. Needleman, Analysis of the cup-cone fracture in a round tensile bar, Acta Metallurgica, 32 (1984) 1, 157-169, doi:10.1016/0001-6160(84)90213-X

${ }^{22}$ A. Needleman, V. Tvergaard, An analysis of ductile rupture modes at a crack tip, Journal of the Mechanics and Physics of Solids, 35 (1987), 151-183, doi:10.1016/0022-5096(87)90034-2

${ }^{23}$ N. Vajragupta, V. Uthaisangsuk, B. Schmaling, S. F. Shaw, A micromechanical damage simulation of dual phase steels using XFEM, Computational Materials Science, 54 (2012), 271-279, doi:10.1016/ j.commatsci.2011.10.035

${ }^{24}$ M. Abendroth, M. Kuna, Determination of deformation and failure properties of ductile materials by means of the small punch test and neural networks, Computational Materials Science, 28 (2003) 3, 633-644, doi:10.1016/j.commatsci.2003.08.031

${ }^{25}$ J. Faleskog, X. Gao, C. F. Shih, Cell model for nonlinear fracture analysis - I. Micromechanics calibration, International Journal of Fracture, 89 (1998) 4, 355-373, doi:10.1023/A:1007421420901

${ }^{26}$ C. C. Chu, A. Needleman, Void nucleation effects in biaxially stretched sheets, Journal of Engineering Materials \& Technology, 102 (1980) 3, 249-256, doi: 10.1115/1.3224807 